\author{
JOANNA JAGODA $^{1}$
}

\title{
Podział kompetencji między jednostkami samorządu terytorialnego w zakresie planowania i zagospodarowania przestrzennego
}

Podział zadań planistycznych $\mathrm{w}$ zakresie zagospodarowania przestrzennego między jednostkami samorządu terytorialnego określa ustawa z dnia 27 marca 2003 r. o planowaniu i zagospodarowaniu przestrzennym ${ }^{2}$. Zgodnie $\mathrm{z}$ art. 3 tej ustawy, do zadań własnych gminy należy kształtowanie i prowadzenie polityki przestrzennej na terenie gminy, w tym uchwalanie studium uwarunkowań i kierunków zagospodarowania przestrzennego oraz miejscowych planów zagospodarowania przestrzennego (z wyjątkiem morskich wód wewnętrznych, morza terytorialnego i wyłącznej strefy ekonomicznej oraz terenów zamkniętych). Z kolei do zadań samorządu powiatowego należy prowadzenie, w granicach swojej właściwości rzeczowej, analiz i studiów z zakresu zagospodarowania przestrzennego, odnoszących się do obszaru powiatu i zagadnień jego rozwoju. Kształtowanie i prowadzenie polityki przestrzennej na obszarze związku metropolitalnego (obszarze metropolitalnym) należy do zadań związku metropolitalnego, jeżeli został utworzony. Natomiast w województwie politykę przestrzenną kształtuje i prowadzi samorząd województwa, do którego zadań należy uchwalanie planu zagospodarowania przestrzennego województwa. Polityka przestrzenna jest również wykonywana na szczeblu państwa - w jej ramach Rada Ministrów przyjmuje koncepcję przestrzennego zagospodarowania kraju.

Przepisy art. 3 ustawy o planowaniu i zagospodarowaniu przestrzennym formułują zatem podstawy podziału zadań i kompetencji między poszczególne szczeble samorządu terytorialnego oraz administrację rządową. Wolą ustawodawcy wiodącą pozycję w systemie planowania przestrzennego zajmuje gmina. Kształtowanie i prowadzenie polityki przestrzennej należy do zadań (własnych) gminy i samorządu województwa oraz do zadań Rady Ministrów. Powiat nie jest podmiotem kształtowania i prowadzenia polityki przestrzennej, lecz może jedynie prowadzić analizy

\footnotetext{
$1 \quad$ Uniwersytet Śląski w Katowicach.

2 Ustawa z dnia 27 marca 2003 r. o planowaniu i zagospodarowaniu przestrzennym, tekst jedn. Dz.U. z 2016 r. poz. 778 , dalej w skrócie u.p.z.p.
} 
i studia z zakresu zagospodarowania przestrzennego w granicach swojej właściwości rzeczowej.

Wykładnia przepisów art. 3 u.p.z.p. powinna być dokonywana w kontekście odpowiednich przepisów Konstytucji ${ }^{3}$ oraz trzech samorządowych ustaw ustrojowych $^{4}$.

Z Konstytucji wynikają - poza ogólnymi zasadami pomocniczości i jej istotnego aspektu w postaci decentralizacji władzy publicznej (art. 15 ust. 1 Konstytucji) istotne domniemania zadań, tj. uznanie, że jeżeli podejmowanie danej kwestii może, z uwzględnieniem zasady legalizmu (art. 7 Konstytucji: „,organy władzy publicznej działają na podstawie i w granicach prawa"), stanowić realizację zadania publicznego, a realizacji tego zadania nie zastrzeżono wyraźnie na rzecz innych organów władz publicznych, należy ono do tej władzy publicznej, która korzysta z tego domniemania. Są to:

- domniemanie właściwości Rady Ministrów w sprawach polityki państwa (art. 146 ust. 2 Konstytucji);

- z powyższym zastrzeżeniem, domniemanie zadań i kompetencji jednostek samorządu terytorialnego (art. 163 Konstytucji) - powiązane z ogólnym przypisaniem samorządowi terytorialnemu istotnej części zadań publicznych (art. 16 ust. 2 Konstytucji) i mające podbudowę w art. 4 ust. 3 Europejskiej Karty Samorządu Lokalnego ${ }^{5}$, która, jako umowa międzynarodowa ratyfikowana i ogłoszona w Dzienniku Ustaw, ma pierwszeństwo przed ustawami (art. 241 ust. 1 w zw. z art. 91 ust. 1 i 2 Konstytucji): „Generalnie odpowiedzialność za sprawy publiczne powinny ponosić przede wszystkim te organy władzy, które znajdują się najbliżej obywateli. Powierzając te funkcje innemu organowi władzy, należy uwzględnić zakres i charakter zadania oraz wymogi efektywności i gospodarności";

- w obrębie samorządu terytorialnego domniemanie zadań i kompetencji gminy (art. 164 ust. 3 Konstytucji).

Konstytucja zapewnia jednostkom samorządu terytorialnego samodzielność, która podlega ochronie sądowej (art. 165 ust. 2 Konstytucji), przy czym gwarancję tę trzeba odczytywać w kontekście art. 4 ust. 2 EKSL: „Społeczności lokalne mają - w zakresie określonym prawem - pełną swobodę działania w każdej sprawie, któlej w skrócie u.s.g.; ustawa z dnia 5 czerwca 1998 r. o samorządzie powiatowym, tekst jedn. Dz.U. z 2016 r. poz. 814 ze zm., dalej w skrócie u.s.p.; ustawa z dnia 5 czerwca 1998 r. o samorządzie województwa, tekst jedn. Dz.U. z 2016 r. poz. 486, dalej w skrócie u.s.w. 
ra nie jest wyłączona $\mathrm{z}$ ich kompetencji lub nie wchodzi w zakres kompetencji innych organów władzy".

Samodzielność jednostek samorządu terytorialnego w odniesieniu do problematyki planowania i zagospodarowania przestrzennego na poziomie gminy łączy się z przyjmowaną w polskim orzecznictwie i doktrynie zasadą władztwa planistycznego gminy (od której mogą występować wyjątki ustawowe ${ }^{6}$, jak wyjątek wynikający z art. 51 ust. 1 pkt 3 u.p.z.p. oraz z przepisów dotyczących szczególnych obszarów, o których mowa w art. 3 ust. 1 u.p.z.p.).

Przepisy dwóch ustrojowych ustaw samorządowych wprost wskazują zadania odpowiedniej jednostki samorządu terytorialnego (gminy i województwa samorządowego) w zakresie planowania i zagospodarowania przestrzennego: w art. 7 ust. 1 pkt 1 u.s.g. termin ,ład przestrzenny” użyty został w celu oznaczenia jednego z przedmiotów zadań własnych gminy, a w art. 11 ust. 1 pkt 5 u.s.w. - dla oznaczenia jednego z celów, którym, ustalając strategię rozwoju województwa, powinien kierować się samorząd wojewódzki (niezależnie od odrębnie sygnalizowanych kompetencji w zakresie zagospodarowania przestrzennego określonych w ustawach - art. 14 ust. 1 pkt 7 u.s.w.). Natomiast w ustawie o samorządzie powiatowym terminy ,ład przestrzenny” ani ,zagospodarowanie przestrzenne” nie występują, co potwierdza wniosek płynący z treści art. 3 ust. 2 u.p.z.p., z którego wynika, że powiat nie jest podmiotem kształtowania i prowadzenia polityki przestrzennej.

Władztwo planistyczne gminy to przyznana przepisami prawa możność określania przez tę jednostkę samorządu terytorialnego warunków zagospodarowania przestrzeni ${ }^{7}$. Władztwo planistyczne nie oznacza przy tym autonomii gminy w tym zakresie. Władztwo istnieje w takim zakresie, w jakim określają je ustawy. To ustawodawca, a nie gmina, decyduje o zakresie tego władztwa. Jeżeli zatem z ustaw wynikają określone ograniczenia w rozstrzyganiu o przeznaczeniu terenów, to niewątpliwie wiążą one gminę, a ich nieprzestrzeganie (naruszenie) skutkuje nieważnością planu w całości lub części ${ }^{8}$. Określając zakres władztwa planistycznego, Naczelny Sąd Administracyjny podkreślił, że nie można racjonalnie założyć, iż każda czynność organu gminy podejmowana w ramach przyznanego jej władztwa planistycznego wymaga konkretnego przepisu upoważniającego. Przyjęcie takiego poglądu, zdaniem NSA, oznaczałoby przekreślenie istoty władztwa, u podstaw którego leży samodzielne decydowanie o przeznaczeniu i zasadach zagospodarowania

Por. I. Chojnacka, Władztwo planistyczne gminy w orzecznictwie sądów administracyjnych i Trybunału Konstytucyjnego, „Samorząd Terytorialny” 2009, nr 1-2, s. 86 i nast.; W. Jakimowicz, O normatywnych podstawach władztwa planistycznego gminy, (w:) I. Zachariasz (red.), Kierunki reformy prawa planowania i zagospodarowania przestrzennego, Warszawa 2012, s. 70 i nast.

7 Z. Czarnik, Istota i zakres władztwa planistycznego gminy, „Administracja: teoria, dydaktyka, praktyka” 2010, nr 3, s. 9.

8 Wyrok WSA w Krakowie z dnia 23 czerwca 2008 r., II SA/Kr 314/08, Lex nr 499869 oraz wyrok NSA z dnia 7 grudnia 2007 r., II OSK 1379/07, Lex nr 356085. 
określonych obszarów. Wystarczającą podstawą do działania w ramach władztwa planistycznego, w ocenie Naczelnego Sądu Administracyjnego, jest zespół przepisów u.p.z.p., w szczególności art. 3 ust. 1 u.p.z.p. ${ }^{9}$ Stanowisko to, które wyjaśnia sposób rozumienia w odniesieniu do planowania przestrzennego w gminie zasady legalizmu, wyrażonej w art. 7 Konstytucji, oznacza zarazem zastosowanie w tym zakresie ogólnej zasady samodzielności jednostek samorządu terytorialnego, o której mowa w art. 165 ust. 2 Konstytucji.

O ile można mówić o dużej niezależności gminy, jej samodzielności planistycznej określanej często jako władztwo planistyczne, o tyle zadania powiatu w tym zakresie są znacznie ograniczone. Sprowadzają się do opracowywania analiz i studiów mogących stanowić jedynie podstawę niewiążącej opinii starosty, odnoszącej się do projektu studium uwarunkowań i kierunków zagospodarowania przestrzennego gminy ${ }^{10}$. Taki rozdział kompetencji między gminą a powiatem wzbudza wątpliwości u niektórych przedstawicieli doktryny ${ }^{11}$, którzy podnoszą, iż powiat powinien mieć w stosunku do swojego terytorium przynajmniej minimalne uprawnienia władcze. Proponuje się zatem przyznanie powiatowi z jednej strony pewnych uprawnień, z drugiej zaś - obowiązków w zakresie planowania przestrzennego. Wszystko to miałoby odbyć się kosztem ograniczenia obowiązków władz gminy, jak również częściowej utraty jej samodzielności. Polemizując z tym poglądem trzeba przede wszystkim zauważyć, że powiat nie stanowi ponadlokalnej jednostki samorządu terytorialnego, ale jest uzupełnieniem systemu samorządu lokalnego. Główną przesłanką koncepcji tworzenia powiatu było właśnie dopełnienie samorządności na szczeblu lokalnym. Nie ma też mowy o ponadlokalnym szczeblu samorządu terytorialnego w Konstytucji. Ustawa zasadnicza w art. 164 jednoznacznie rozstrzyga kwestię istnienia gminy, a potencjalnie wypowiada się także o innych jednostkach samorządu regionalnego albo lokalnego i regionalnego, odsyłając w tym zakresie do ustawy zwykłej. Z tego punktu widzenia powołanie dodatkowego rodzaju samorządu lokalnego nie musiało nastąpić ${ }^{12}$. Konstytucja wprowadza zatem podział samorządu terytorialnego na lokalny i regionalny (o utworzeniu tego ostatniego ostatecznie nie przesądzając). Konsekwentnie podział ten został zachowany także w ustawach samorządowych. Ustawa o samorządzie gminnym zalicza do zakresu działania gminy wszystkie sprawy publiczne o znaczeniu lokalnym, niezastrzeżone ustawami na rzecz innych podmiotów (art. 6 ust. 1). Na gruncie ustawy o samo-

9 II OSK 1191/07, Lex nr 400451.

10 
rządzie powiatowym mieszkańcy powiatu tworzą z mocy prawa lokalną wspólnotę samorządową, przez pojęcie powiatu należy zaś rozumieć lokalną wspólnotę samorządową oraz odpowiednie terytorium (art. 1). Szczególnie należy zaakcentować, że na mocy art. 4 ust. 1 u.s.p. powiat wykonuje określone ustawami zadania publiczne o charakterze ponadgminnym. Nie są to jednak zadania o znaczeniu ponadlokalnym. O takich można by mówić tylko w przypadku samorządu województwa, chociaż odnosząca się do tej jednostki samorządu terytorialnego ustawa o samorządzie województwa nie używa tego pojęcia. Mowa jest tu o regionalnej wspólnocie samorządowej (art. 1) oraz o zadaniach o charakterze wojewódzkim (art. 14 ust. 1).

Również w literaturze przedmiotu zgodnie przyjmuje się, że powiat jest jednostką samorządu lokalnego, a nie ponadlokalnego ${ }^{13}$. Reforma administracji publicznej z 1998 r. przyniosła czytelny rozdział funkcji władzy publicznej między trzy główne segmenty ustroju administracyjnego państwa: samorząd lokalny (w gminach i powiatach) - odpowiedzialny przede wszystkim za zaspokajanie zbiorowych potrzeb miejscowych społeczności i bieżącą administrację, samorząd regionalny (w województwach) - odpowiedzialny za politykę rozwoju regionalnego, rząd i administrację rządową (centralną i terenową) - z odpowiedzialnością za sprawy o charakterze ogólnopaństwowym, a także za przestrzeganie prawa i nadzór w tym zakresie nad samorządem (wojewodowie) ${ }^{14}$. W piśmiennictwie zaznacza się również, że zadania jednostek samorządu terytorialnego ,są istotnym elementem ich statusu prawnego, są też kryterium pozwalającym na rozróżnienie jednostek podstawowych - gmin, powiatów jako pośredniego szczebla samorządu i regionalnych jednostek samorządu terytorialnego"15.

Określanie powiatu ponadlokalnym szczeblem samorządu terytorialnego burzy ten czytelny podział funkcji władzy publicznej w państwie, jest sprzeczne z istniejącymi rozwiązaniami ustrojowymi. Wprowadza również chaos w podziale zadań i kompetencji w zakresie zagospodarowania przestrzennego. Dlatego nie można mówić o powiecie jako szczeblu ponadlokalnym, istnieje on na poziomie lokalnym, ponadgminnym, jest to pośredni szczebel samorządu terytorialnego. Warto dodać, że podział samorządu terytorialnego na lokalny i regionalny występuje nie tylko na gruncie polskich rozwiązań prawnych. Polski ustawodawca wzorował się w tym zakresie na innych państwach Europy. Ogólnoeuropejskie zasady i standardy samo-

Por. np. S. Wykrętowicz, Samorząd jako wyraz demokracji obywatelskiej, (w:) S. Wykrętowicz (red.), Samorząd w Polsce. Istota, formy, zadania, Poznań 2008, s. 77; H. Izdebski, Samorząd terytorialny. Podstawy ustroju i działalności, Warszawa 2006, s. 112; B. Dolnicki, Samorząd terytorialny, Warszawa 2016, s. 146 i nast.

14 M. Kulesza, Gminy, powiaty i województwa, (w:) M. Kulesza, L. Węgrzyn, Vademecum skutecznego działania w samorządzie, Warszawa 2006, s. 21.

15 M. Stahl, Status powiatu - zagadnienia wybrane, (w:) S. Dolata (red.), Prawne i finansowe aspekty funkcjonowania samorządu terytorialnego. Tom I. Prawo samorządowe i administracyjne, Opole 2000, s. 267. Podobnie B. Dolnicki, Samorząd..., op. cit., s. 350 i nast. 
rządu terytorialnego odzwierciedlają Europejska Karta Samorządu Lokalnego oraz Europejska Karta Samorządu Regionalnego (dotychczas nieratyfikowana) ${ }^{16}$.

Poszerzenie zadań planistycznych powiatu mogłoby polegać, w myśl wspomnianych już propozycji przedstawionych w literaturze przedmiotu ${ }^{17}$, na rozdzieleniu kompetencji dotyczących planowania przestrzennego między gminą a powiatem w ten sposób, aby gminie pozostawić sporządzanie miejscowych planów zagospodarowania przestrzennego, powiatowi zaś powierzyć opracowywanie studium uwarunkowań i kierunków zagospodarowania przestrzennego. Chodzi o wprowadzenie nowego dokumentu planistycznego, który nie odnosiłby się już tylko do gminy, ale do obszaru powiatu (,studium uwarunkowań i kierunków zagospodarowania przestrzennego powiatu”). Zdaniem zwolenników tej koncepcji, studium lepiej spełniałoby swoją funkcję, obejmując obszar powiatu, a nie tylko gminy.

Do powyższej koncepcji krytycznie odniosła się Katarzyna Wlaźlak, wskazując na wiążące się z tą propozycją naruszenie podstawowych zasad ustrojowych państwa, w tym konstytucyjnych ${ }^{18}$. Autorka słusznie zauważa, że podstawową jednostką samorządu terytorialnego jest gmina i to do niej generalnie należy wykonywanie zadań lokalnych - zgodnie z określoną w Konstytucji zasadą domniemania kompetencji samorządu terytorialnego na rzecz gminy (art. 164 ust. 3) oraz art. 6 ust. 1 u.s.g. stanowiącym, że do zakresu działania gminy należą wszystkie sprawy publiczne o znaczeniu lokalnym, niezastrzeżone ustawami na rzecz innych podmiotów. W piśmiennictwie rozwiązanie to nazywane jest domniemaniem właściwości gminy w publicznych sprawach lokalnych ${ }^{19}$. Dodatkowo art. 6 ust. 2 u.s.g. przyznaje gminie kompetencję rozstrzygania w tego rodzaju sprawach (jeżeli ustawy nie stanowią inaczej). Jednostka samorządu terytorialnego każdego szczebla ma własny, odrębny zakres działania, ale obowiązuje przy tym zasada domniemania kompetencji gminy jako podstawowej jednostki samorządu ${ }^{20}$. Z faktu, iż Konstytucja czyni gminę podstawową jednostką samorządu terytorialnego, wynika konsekwencja prawna, że to gmina spełnia podstawowe zadania tego samorządu ${ }^{21}$.

Takie zadania odnoszą się również do zagospodarowania przestrzennego. Planowanie przestrzenne stanowi istotną i nieodłączną część polityki lokalnej gminy. W jej ramach m.in. opracowuje się studium, które zawiera diagnozę i określa politykę gminy w zakresie zagospodarowania przestrzennego, zwykle w dłuższym cza$\mathrm{sie}^{22}$. Ład przestrzenny i gospodarka nieruchomościami należą do zadań własnych

Europejska Karta Samorządu Regionalnego, sporządzona w Strasburgu dnia 5 czerwca 1997 r., nieratyfikowana przez Polskę.

17 M. Chudak, O nowy kształt..., op. cit., s. 18-24

18 K. Wlaźlak, Głos w sprawie nowego kształtu planowania przestrzennego w powiecie, „Samorząd Terytorialny” 2009, nr 6, s. 70-76.

19 B. Dolnicki, Samorząd terytorialny, s. 350 i nast. 
samorządu gminnego. W art. 7 ust. 1 u.s.g. zadania te zajmują pierwsze miejsce w obszernym katalogu zadań gminy, co niewątpliwie zwiększa ich rangę w całej polityce lokalnej realizowanej przez gminę. Trzeba dodać, że zadania te są ściśle związane $\mathrm{z}$ innymi zadaniami gminy. Zadania ujęte $\mathrm{w}$ planie zagospodarowania przestrzennego oraz w studium uwarunkowań i kierunków zagospodarowania przestrzennego są powiązane z zadaniami nałożonymi na gminę na mocy ustawy o samorządzie gminnym ${ }^{23}$. Niezasadne wydaje się zatem rozdzielenie tych dwóch aktów planowania i przekazanie powiatowi kompetencji do sporządzania jednego $\mathrm{z}$ nich. Zadania gminy w zakresie planowania i zagospodarowania przestrzennego tylko wówczas będą wykonywane w sposób efektywny, gdy zostanie zachowana ich spójność. Studium opracowywane przez samorząd powiatowy nie byłoby dostosowane do warunków i potrzeb lokalnych gminy, ale powiatu. W rezultacie nie mogłyby wówczas spełniać swojej funkcji miejscowe plany zagospodarowania przestrzennego, przy których sporządzaniu ustalenia studium są wiążące dla organów gminy.

Ponadto należy podkreslić, że zakres zadań i funkcje powiatu mają charakter uzupełniający i wyrównawczy w stosunku do funkcji gminy ${ }^{24}$. Zadania powiatu ustalono na zasadzie określenia katalogu zamkniętego i nie ma tu zastosowania, jak to jest w przypadku gminy, domniemanie ogólnej właściwości. Powiat ma wykonywać te zadania związane ze społeczno-gospodarczym rozwojem, których nie może czy nie jest w stanie realizować gmina, a których przekazanie na poziom województwa stanowiłoby znaczne oddalenie tych spraw od społeczności lokalnych. Będąc pośrednim elementem samorządu terytorialnego, powiat ma wypełniać „lukę” między gminą a województwem. Takie rozwiązanie zapewnia racjonalność i przejrzystość władzy. Realizacja propozycji dotycząca przeniesienia kompetencji w zakresie sporządzania studium uwarunkowań i kierunków zagospodarowania przestrzennego z gminy na powiat mogłaby spowodować bałagan w podziale zadań i kompetencji między nimi. Warto wspomnieć, że nakładanie zadań, dublowanie jurysdykcji i pojawiające się na tym tle liczne spory kompetencyjne między jednostkami samorządu lokalnego istnieją już w innych obszarach działań ${ }^{25}$. Trafnie zwrócono uwagę, że istotą planowania na szczeblu gminnym jest tzw. planowanie regulacyjne, na szczeblu państwowym - kształtowanie polityki przestrzennej państwa, natomiast planowanie na szczeblu wojewódzkim pełni funkcję zwornika pomiędzy planowaniem realizacyjnym gminy a polityką państwa ${ }^{26}$. Gdy zaś chodzi o powiat, jego zadania mają charakter niesformalizowany i subsydiarny w stosunku do planowania

J. Sikora, Lokalne układy społeczne, (w:) S. Wykrętowicz (red.), Samorząd w Polsce. Istota, formy, zadania, Poznań 2001, s. 102.

24 K. Wlaźlak, Głos w sprawie..., op. cit., s. 73.

25 Przykładem może być zarządzanie drogami , na co wskazuje K. Wlaźlak, (w:) Głos w sprawie..., op. cit., przypis 18, a także J. Kowalik, Między rywalizacją a współpracą - gmina i powiat po reformie 1998 roku, (w:) J. Parchomiuk, B. Ulijasz, E. Kruk (red.), Dziesięć lat reformy ustrojowej administracji publicznej w Polsce. Ogólnopolska konferencja naukowa, Łańcut, 12-14 czerwca 2008 r., Warszawa 2009, s. 132. 
na trzech wspomnianych wyżej szczeblach. Powiat nie jest zatem odrębnym organem systemu planowania przestrzennego i może być traktowany co najwyżej jako podmiot planowania subwojewódzkiego ${ }^{27}$. Odebranie gminie kompetencji w zakresie sporządzania studium uwarunkowań i kierunków zagospodarowania przestrzennego oraz przekazanie jej powiatowi byłoby sprzeczne z zasadą subsydiarności, zgodnie z którą dane zadanie publiczne powinno być wykonywane na najniższym z możliwych szczebli władz publicznych. Jeżeli gmina może mu podołać, nie trzeba angażować innego szczebla samorządu terytorialnego ${ }^{28}$. Jak stanowi art. 4 ust. 3 EKSL, odpowiedzialność za sprawy publiczne powinny ponosić te organy władzy, które znajdują się najbliżej obywateli. Powierzając te funkcje innemu organowi władzy, należy uwzględnić zakres i charakter zadania oraz wymogi efektywności i gospodarności. W omawianym przypadku został zachowany najbardziej racjonalny podział zadań, nie ma bowiem podstaw do twierdzenia, że powiat wykonałby te zadania w sposób bardziej efektywny niż gmina. Należy podkreślić, że proponowany nowy akt planowania powiatu miałby w swoich ustaleniach generalnie odzwierciedlać te same problemy funkcjonalno-przestrzenne, które występują na szczeblu gminy, tylko w większej skali. Sprzeciw budzi także rozwiązanie, w myśl którego organy powiatowe stwierdzałyby zgodność ustaleń planu miejscowego sporządzanego przez gminę z polityką przestrzenną określoną w studium powiatowym, co miałoby sprzyjać zmniejszeniu zjawiska uznaniowości ze strony gminy. Nie można także zaakceptować propozycji, aby studium uwarunkowań i kierunków zagospodarowania przestrzennego powiatu stanowiło akt prawa miejscowego, uprawniający do bezpośredniego wydawania na jego podstawie decyzji administracyjnych. Akt ten miałby mieć wobec tego charakter prawa powszechnie obowiązującego w rozumieniu art. 87 ust. 2 Konstytucji, czego aktualnie nie przewiduje ustawa o planowaniu i zagospodarowaniu przestrzennym. Ustawodawca nadaje studium gminnemu charakter aktu wewnętrznie obowiązującego na obszarze gminy (niezależnie od tego, że jego ustalenia mogą wpływać w sposób pośredni na prawa i obowiązki podmiotów usytuowanych na zewnątrz administracji). Sam wymóg zgodności planu miejscowego ze studium wynika z ustawy o planowaniu i zagospodarowaniu przestrzennym, obecnie dotyczy to jednak gminy, a nie powiatu. Zgodnie z art. 9 ust. 4 u.p.z.p. ustalenia studium są wiążące dla organów gminy przy sporządzaniu planów miejscowych. Stwierdzanie zgodności planu miejscowego gminy z ustaleniami studium powiatowego przez organy powiatu naruszałoby podstawowe zasady ustrojowe, na których oparty został samorząd terytorialny. Należy podkreślić, że jednostki samorządu terytorialnego nie funkcjonują na zasadzie kierownictwa i podporządkowania. Nie mają kompetencji nadzorczych wobec siebie, co dotyczy zwłaszcza 
województw wobec gmin i powiatów oraz powiatów wobec gmin ${ }^{29}$. Zatem powiat i gmina to dwie niezależnie od siebie działające struktury, względnie samodzielne, będące formą decentralizacji władzy publicznej zapewnionej w art. 15 ust. 1 Konstytucji. Trzeba wspomnieć w tym miejscu o art. 4 ust. 6 u.s.p. stanowiącym, że zadania powiatu nie mogą naruszać zakresu działania gminy. Za podstawową zasadę ustrojową zastosowaną przy kształtowaniu modelu trójszczeblowego samorządu terytorialnego uznaje się zasadę niezależności ustrojowej, organizacyjnej i zadaniowej poszczególnych szczebli samorządu terytorialnego. Charakterystyczną cechą gminy i powiatu (także województwa samorządowego) jest odrębność ustrojowa, czasami określana samotnością ustrojową ${ }^{30}$, każda bowiem jednostka samorządu terytorialnego posiada, ustawowo określony, własny zakres zadań i kompetencji, jest samodzielna i niezależna względem innych jednostek tego samorządu.

Należy podkreślić, że powiatowi ustrojowo został nadany charakter samorządowy, ale zakres jego zadań własnych jest stosunkowo niewielki. Powiat ma również zapewniać wykonywanie ustawowo określonych zadań i kompetencji kierowników powiatowych służb, inspekcji i straży. Zadania te wchodzą w zakres działania administracji rządowej, a są realizowane pod zwierzchnictwem starosty. Istniejące dysproporcje ilościowe między zadaniami własnymi a zadaniami administracji rządowej wykonywanymi przez powiat stanowią nierzadko podstawę formułowania pytań o ich samorządowy, rządowy czy też mieszany charakter ${ }^{31}$. W doktrynie badano również zasadność utworzenia pośredniego szczebla samorządu terytorialnego $^{32}$. Podkreślano, że z punktu widzenia charakteru realizowanych zadań powiat jest zbliżony bardziej do administracji rządowej niż samorządowej ${ }^{33}$. Nie znaczy to jednak, że trzeba szukać dla powiatu zadań typu samorządowego w zakresie zadań własnych gminy. Można dodać, że podobny model powiatu (subregionu) typowy jest dla wielu innych państw, gdzie powszechne jest także występowanie dużej samodzielności gminy w sprawach planowania i zagospodarowania przestrzennego z jednoczesnym ograniczeniem kompetencji powiatu w tym zakresie.

Jak słusznie zauważa K. Wlaźlak, za pozostawieniem opracowywania studium uwarunkowań i kierunków zagospodarowania przestrzennego w zakresie zadań gminy dodatkowo przemawia fakt niewystarczających środków finansowych posiadanych przez samorządy powiatowe. Problem braku pieniędzy na realizację za-

29 L. Kieres, Samorząd terytorialny jako instytucja społeczeństwa obywatelskiego, „Ruch Prawniczy, Ekonomiczny i Socjologiczny" 2006, nr 2, s. 183.

30 M. Stahl, Samotność ustrojowa samorządu terytorialnego - prawda czy fałsz?, (w:) Dziesięć lat reformy ustrojowej..., op. cit., s. 23.

31 Por. P. Niemczuk, Rola szczebla pośredniego w koncepcji samorządu terytorialnego - ujęcie funkcjonalne, (w:) Dziesięć lat reformy ustrojowej..., op. cit., s. 108 i nast.; B. Dolnicki, Samorząd terytorialny, s. 358-363.

32 Zob. np. B. Zawadzka, Czy potrzebne sąpowiaty?, „Państwo i Prawo” 1994, z. 11, s. 9-15; J.T. Hryniewicz, Powiaty i regiony w Polsce, „Samorząd Terytorialny” 1995, nr 7-8, s. 85-91.

33 E. Knosala, Zadania powiatu i mechanizmy prawne ich kształtowania, (w:) J. Boć (red.), Powiat, Wrocław 2001, s. 56 . 
dań własnych dotyczy, co prawda, wszystkich jednostek samorządu terytorialnego, ale w przypadku powiatu jest on szczególnie widoczny. W proponowanym nowym kształcie planowania przestrzennego w powiecie brakuje propozycji dodatkowego finansowania zadania powiatu dotyczącego sporządzania i wykonywania nowego aktu planowania, którym jest studium uwarunkowań i kierunków zagospodarowania przestrzennego. Środki, którymi dysponuje powiat, są zbyt skromne i zwykle i tak nie wystarczają na wykonywanie bardzo kosztownych zadań własnych. W praktyce znane jest zjawisko oczekiwania od gmin, funkcjonujących na obszarze powiatu, współfinansowania podejmowanych przez niego inwestycji i działań. Spotyka się to najczęściej z odmową przez gminy partycypacji w kosztach przedsięwzięć powiatu, a nawet z pytaniem o zasadność istnienia takiego szczebla samorządu terytorialnego, który powstał poprzez odebranie części kompetencji gminom, nie posiada wystarczających środków na podejmowane przedsięwzięcia, za to konsumuje olbrzymie środki na utrzymanie własnej administracji ${ }^{34}$. Istnieje wobec tego uzasadniona obawa, że powiat nie będzie również w stanie pokryć bardzo wysokich kosztów sporządzania studium uwarunkowań i kierunków zagospodarowania przestrzennego. Należy pamiętać, że dokument ten obejmuje zarówno część tekstową, jak i graficzną, jego przygotowanie wymaga opracowania niezbędnych analiz i projektów, skomplikowana jest ponadto sama procedura uchwalania studium. Gdyby zadania te miały być realizowane kosztem obciążenia finansowego gminy, to nie widać sensu przenoszenia ich na poziom powiatu. Gminy w znacznie szerszym zakresie niż powiaty charakteryzuje niezależność finansowa, ich budżety w ponad połowie stanowią dochody własne. W przypadku powiatów jest to zaledwie kilka procent, zdecydowaną większość ich dochodów stanowią natomiast dotacje i subwencje. Biorąc pod uwagę, że to właśnie poziom dochodów własnych określa realne możliwości samorządu terytorialnego, jest głównym wyznacznikiem jego samodzielności ${ }^{35}$, to można mówić o braku zdolności samorządu powiatowego do wykonywania zadania polegającego na sporządzaniu studium uwarunkowań i kierunków zagospodarowania przestrzennego.

Wyposażenie powiatu w dodatkowe kompetencje planistyczne kosztem ograniczenia samodzielności gminy nie jest właściwym rozwiązaniem. Przeniesienie zadań dotyczących sporządzania studium uwarunkowań i kierunków zagospodarowania przestrzennego $\mathrm{z}$ gminy na powiat byłoby sprzeczne $\mathrm{z}$ podstawowymi założeniami ustrojowymi państwa oraz z zasadami funkcjonowania samorządu terytorialnego w Polsce. Spowodowałoby naruszenie zasad decentralizacji, subsydiarności, samodzielności samorządu terytorialnego czy domniemania kompetencji gminy jako podstawowej jednostki tego samorządu. Gmina realizuje politykę lokalną m.in. ponr 2, s. 138. 
przez wykonywanie zadań w zakresie planowania i zagospodarowania przestrzennego. Stanowią one istotną i nieodłączną część tej polityki. Ani zasięg, ani też ciężar gatunkowy tych zadań nie przekracza możliwości gmin. Można zauważyć wysoką efektywność ich wykonywania przez gminy, zarówno pod względem organizacyjnym, jak i finansowym. Z kolei powiat nie dysponuje takim potencjałem. Uzasadnia to zachowanie dotychczasowego podziału zadań w systemie gospodarowania przestrzenią, w którym powiat pełni funkcję uzupełniającą w stosunku do funkcji gminy. Postanowienia studium są wiążące dla organu sporządzającego plan miejscowy, zatem gdyby studium opracowywał powiat, realizowałby tym samym politykę zagospodarowania przestrzennego gminy.

Rozpatrując kwestię podziału kompetencji między jednostkami samorządu terytorialnego w zakresie planowania i zagospodarowania przestrzennego, trzeba mieć na uwadze konstytucyjną zasadę samodzielności jednostek samorządu terytorialnego, w tym także w aspekcie zadaniowo-kompetencyjnym. Samodzielność ta może być rozpatrywana nie tylko w kontekście relacji samorząd - państwo, ale również w ramach stosunków zachodzących pomiędzy poszczególnymi jednostkami samorządu terytorialnego. Ten aspekt samodzielności (który może też być określany jako „niezależność” poszczególnych jednostek samorządu terytorialnego względem siebie) wyrażony został w szczególności w art. 4 ust. 6 u.s.p. oraz w art. 4 ust. 2 u.s.w., stosownie do których zakres działania jednostek samorządu terytorialnego wyższego rzędu nie może naruszać samodzielności (niezależności) jednostek niższego rzędu (powiatów i gmin). Analiza obecnych regulacji prawnych dotyczących kompetencji planistycznych gmin, powiatów i województw samorządowych pozwala na stwierdzenie, iż ustawodawca przyjął uznawaną powszechnie w państwach Unii Europejskiej koncepcję trzech podstawowych poziomów planowania przestrzennego (tj. planowania ogólnopaństwowego, regionalnego i gminnego), nadając jednocześnie działaniom na szczeblu powiatu charakter komplementarny, a przy tym zapewniając realizację zasady samodzielności kompetencyjnej poszczególnych jednostek samorządu terytorialnego. 
DIVISION OF COMPETENCIES AMONG THE LOCAL GOVERNMENT UNITS AS REGARDS PLANNING AND SPATIAL DEVELOPMENT

Keywords: division of competencies, local government units, planning and spatial development

The division of planning tasks as regards spatial development among the local government units is defined by the act of the 27th of March 2003 on planning and spatial development. Pursuant to article 3 of this act, the scope of the commune's own tasks shall comprise shaping and conducting spatial policy located within the commune, including the resolution of the study of determinants and the directions of spatial development and local plans of spatial development (except for internal maritime waters, territorial sea waters and exclusive economic zone and closed territories). On the other hand, the scope of the county self-government tasks shall comprise conducting, within the bounds of its ratione materiae competence, the analyses and studies of spatial development regarding the county area and the issues of its development. Shaping and conducting spatial policy within the area of metropolitan union (metropolitan area) belongs to the tasks of the metropolitan union if such a union was created. However, in a province spatial policy is shaped and conducted by the province self-government, whose tasks comprise the resolution of the spatial development plan of the province.

Bibliografia:

Chmielnicki P., Świadczenie usług przez samorząd terytorialny w Polsce. Zagadnienia ustrojowoprawne, Warszawa 2005.

Chojnacka I., Władztwo planistyczne gminy w orzecznictwie sądów administracyjnych i Trybunału Konstytucyjnego, ,Samorząd Terytorialny” 2009, nr 1-2.

Chudak M., O nowy kształt planowania przestrzennego w powiecie, „Samorząd Terytorialny” 2008, nr 3.

Czarnik Z., Istota i zakres władztwa planistycznego gminy, ,Administracja: teoria, dydaktyka, praktyka" 2010, nr 3.

Dolnicki B. (red.), Ustawa o samorządzie powiatowym. Komentarz, Warszawa 2007.

Dolnicki B., Samorząd terytorialny, Warszawa 2016.

Heller J., Samodzielność finansowa samorządów terytorialnych w Polsce, ,, Studia Regionalne i Lokalne" 2006, nr 2.

Hryniewicz J.T., Powiaty i regiony w Polsce, „, Samorząd Terytorialny” 1995, nr 7-8.

Izdebski H., Samorząd terytorialny. Podstawy ustroju i działalności, Warszawa 2006.

Jakimowicz W., O normatywnych podstawach władztwa planistycznego gminy, (w:) I. Zachariasz (red.), Kierunki reformy prawa planowania i zagospodarowania przestrzennego, Warszawa 2012. 
Kieres L., Samorząd terytorialny jako instytucja społeczeństwa obywatelskiego, „Ruch Prawniczy, Ekonomiczny i Socjologiczny” 2006, nr 2.

Knosala E., Zadania powiatu i mechanizmy prawne ich kształtowania, (w:) J. Boć (red.), Powiat, Wrocław 200.1

Kowalik J., Między rywalizacją a współpracą - gmina i powiat po reformie 1998 roku, (w:) J. Parchomiuk, B. Ulijasz, E. Kruk (red.), Dziesięć lat reformy ustrojowej administracji publicznej w Polsce. Ogólnopolska konferencja naukowa, Łańcut, 12-14 czerwca 2008 r., Warszawa 2009.

Kulesza M., Gminy, powiaty i województwa, (w:) M. Kulesza, L. Węgrzyn, Vademecum skutecznego działania w samorządzie, Warszawa 2006.

Niemczuk P., Rola szczebla pośredniego w koncepcji samorządu terytorialnego - ujęcie funkcjonalne, (w:) Dziesięć lat reformy ustrojowej administracji publicznej w Polsce. Ogólnopolska konferencja naukowa, Łańcut, 12-14 czerwca 2008 r., Warszawa 2009.

Niewiadomski Z., Planowanie przestrzenne. Zarys systemu, Warszawa 2002.

Niewiadomski Z. (red.), Planowanie i zagospodarowanie przestrzenne. Komentarz, Warszawa 2008.

Sikora J., Lokalne układy społeczne, (w:) S. Wykrętowicz (red.), Samorząd w Polsce. Istota, formy, zadania, Poznań 2001.

Skrzydło W., Konstytucja Rzeczypospolitej Polskiej, Warszawa 2007.

Stahl M., Status powiatu - zagadnienia wybrane, (w:) S. Dolata (red.), Prawne i finansowe aspekty funkcjonowania samorządu terytorialnego. Tom I. Prawo samorządowe i administracyjne, Opole 2000.

Stahl M., Samotność ustrojowa samorządu terytorialnego - prawda czy fałsz?, (w:) Dziesięć lat reformy ustrojowej administracji publicznej w Polsce. Ogólnopolska konferencja naukowa, Łańcut, 12-14 czerwca 2008 r., Warszawa 2009

Wlaźlak K., Głos w sprawie nowego kształtu planowania przestrzennego w powiecie, „, Samorząd Terytorialny" 2009, nr 6.

Wykrętowicz S., Samorząd jako wyraz demokracji obywatelskiej, (w:) S. Wykrętowicz (red.), Samorząd w Polsce. Istota, formy, zadania, Poznań 2008.

Zawadzka B., Czy potrzebne są powiaty?, „Państwo i Prawo” 1994, z. 11. 